九州大学学術情報リポジトリ

Kyushu University Institutional Repository

\title{
Allelopathic Effects of Skeletonema spp. May Influence Interspecific Competition and Bloom Formation of Co-occurring Harmful Flagellates
}

Qiu, Xuchun

Shimasaki, Yohe i

Department of Bioresource Sciences, Faculty of Agriculture, Kyushu University

Yoshida, Yukifumi

Saga Prefectural Genkai Fisheries Research and Development Center

Matsubara, Tadashi

Saga Prefectural Ariake Fisheries Research and Development Center

他

https://doi.org/10.5109/1467649

出版情報：九州大学大学院農学研究院紀要. 59 (2)，pp.373-382，2014-08-29. Faculty of Agriculture, Kyushu University

バージョン：

権利関係 : 


\title{
Allelopathic Effects of Skeletonema spp. May Influence Interspecific Competition and Bloom Formation of Co-occurring Harmful Flagellates
}

\author{
Xuchun QIU*, Yohei SHIMASAKI, Yukifumi YOSHIDA ${ }^{1}$, Tadashi MATSUBARA², \\ Yasuhiro YAMASAKI ${ }^{3}$, Mayumi KAWAGUCHI ${ }^{1}$, Masato HONDA, \\ Kentaro MOURI, Yu NAKAJIMA, Rumana TASMIN, \\ Katsutoshi KUNO ${ }^{4}$, Yoshio KAWAMURA, \\ Tsuneo HONJO ${ }^{5}$ and Yuji OSHIMA
}

\author{
Laboratory of Marine Environmental Science, Division of Animal \& Marine Bioresource Science, \\ Department of Bioresource Sciences, Faculty of Agriculture, \\ Kyushu University, Fukuoka 812-8581, Japan \\ (Received April 25, 2014 and accepted May 12, 2014)
}

\begin{abstract}
We investigated the allelopathic effects of Skeletonema spp. on growth and interspecific competition of the co-occurring flagellates Akashiwo sanguinea, Chattonella spp., and Heterosigma akashiwo, by reviewing field data on fluctuations in their cell densities and through laboratory experiments. From 29 June to 3 September, 2007, three dense blooms were observed in the inner part of the Ariake Sea, Japan. In all the 4 stations, Skeletonema spp. were generally detected and contributed to blooms from 20 to 23 July and from 6 to 13 August. Chattonella spp. gradually grew from mid-July and formed mixed blooms with Skeletonema spp. from 6 to 13 August, and then caused an almost mono-specific bloom in the station 2 and 3 from 20 to 24 August. However, H. akashiwo and A. sanguinea generally maintained low cell densities. Laboratory experiments showed that when grown in re-enriched culture filtrates of Skeletonema sp. (NIES-324) and cultured with Skeletonema sp. under non-contact conditions, A. sanguinea suffered the highest growth inhibitory effect, followed by $H$. akashiwo, while $C$. antiqua was the most resistant species. In tri-algal culture of these flagellates, the allelopathic effects of Skeletonema sp. increased the proportion of $C$. antiqua cells and decreased those of $H$. akashiwo and $A$. sanguinea, perhaps giving $C$. antiqua a competitive advantage over the other 2 flagellates. Our results suggest that allelopathy of Skeletonema spp. has potential to influence interspecific competition of these flagellates owing to species-specific growth inhibitory levels, and sometimes may be propitious to bloom formation of Chattonella spp. in the field.
\end{abstract}

Key words: allelopathy, flagellates, interspecific competition, Skeletonema spp.

\section{INTRODUCTION}

Allelopathy refers to any direct or indirect inhibitory or stimulatory effect of one plant on another through the production of chemical secretions (Maestrini and Bonin, 1981; Rice, 1984). In aquatic systems, allelopathy has been emphasized to regulate both community composition and harmful algal bloom (HAB) dynamics (Honjo, 1993; Smayda, 1997; Granéli and Hansen, 2006; Granéli et al., 2008). Although allelopathy is becoming increasingly appreciated based upon laboratory results, some recent studies have thrown doubt on its involvement in the process of algal bloom initiation (Flynn, 2008; Jonsson et al., 2009). Allelopathic effects in a natural environment, which may be modified by abiotic and biotic factors, may sometimes not be as obvious or even be contrary to that predicted from laboratory studies (e.g. Suikkanen et

Saga Prefectural Genkai Fisheries Research and Development Center, Tobo 6-4948-9, Karatsu, Saga 847-0122, Japan

Saga Prefectural Ariake Fisheries Research and Development Center, Nagata 2753-2, Ashikari-cho, Ogi, Saga 849-0313, Japan

National Fisheries University, Nagata-Honmachi 2-7-1, Shimonoseki 759-6595, Japan

${ }^{4}$ Fisheries Division, Production Promotion Department, Saga Prefectural Goverment, Jonai 1-1-59, Saga 840-8570, Japan

Seto Inland Sea Regional Research Center, Kagawa University, Saiwaichou 1-1, Takamatsu, Kagawa 760-8521, Japan

* Corresponding author (E-mail: xuchunqiu@gmail.com) al., 2005; Poulson et al., 2010). On the other hand, more and more micro- or mesocosm studies have demonstrated the role of allelopathy in regulating marine microbial communities, and emphasized the importance of considering multiple interactions among species simultaneously in nature (Fistarol et al., 2004; Weissbach et al., 2011). Further field-based and multi-species studies are therefore needed to investigate the role of allelopathy observed in laboratory-based studies in regulating community composition and bloom formation (Legrand et al., 2003; Tillmann et al., 2007; Weissbach et al. 2011).

Over the last 30 years, HABs have tended to occur more frequently and caused serious damage to aquaculture and fishery production in the Ariake Sea, Japan (Tsutsumi, 2006). The raphidophytes Heterosigma akashiwo (Y. Hada) Y. Hada ex Y. Hara and M. Chihara, Chattonella spp. [Chattonella antiqua (Hada) Ono and Chattonella marina (Subrahmanyan) Hara et Chihara] and the dinoflagellate Akashiwo sanguinea (K. Hirasaka) G. Hansen \& Ø. Moestrup, are representative harmful flagellates in this area, and frequently tend to form blooms from late April to July, from July to late September, and from October to December, respectively (Nakamura and Hirata, 2006; Tsutsumi, 2006; Yamatogi et al., 2006). Although these flagellates have been indicated to have a sufficient potential to form blooms in summer in the Ariake Sea from the viewpoint of their physiological characteristics (Matsubara et al., 2007; Yamatogi 
et al., 2006), their blooms have rarely been observed to co-occur during this season. Growth interactions through allelopathy were also suggested to have a role in regulating interspecies competition among these flagellates, and $C$. antiqua at higher cell density exhibits some advantages over the 2 other species in forming dominant blooms. However, the combination of initial cell densities of these flagellates are critical in determining the successful species of growth competition in bi-algal cultures, and the species that first reached the early stationary phase tends to strongly inhibit growth of the other alga (Qiu et al., 2011a, 2011b). Considering that any member of different phytoplankton species may affect interspecific interactions in a complex plankton community, other co-existing algae may also play roles in determining which particular species will form a dominant bloom.

Diatoms Skeletonema spp. are common throughout the year and frequently dominate the phytoplankton community in spring and summer in the Ariake Sea (Tsutsumi, 2006). Previous studies have suggested that Skeletonema sp. has species-specific allelopathic effects on phytoplankton (Imada et al., 1991; Yamasaki et al., 2011) and is strong competitors of harmful flagellates. For example, in spring and summer in Hakozaki Harbor, Japan, bloom of Skeletonema costatum (Greville) Cleve played an important role in inhibiting the growth of $A$. sanguinea (Matsubara et al., 2008), while H. akashiwo and $S$. costatum exhibited mutual inhibitory effects and alternated in forming dense blooms (Honjo et al. 1978; Yamasaki et al., 2007). During summer in the inner part of the Ariake Sea, Chattonella spp. have sometimes formed dense blooms in combination with Skeletonema spp., while the cells of other flagellates have generally been at relatively low densities (Matsubara et al., 2009; Katano et al., 2012). It is therefore reasonable to consider that the allelopathy of Skeletonema spp. has the potential to affect bloom formation of these co-occurring flagellates.

We report the dynamics of some predominant phytoplankton species (diatoms Skeletonema spp.; flagellates A. sanguinea, Chattonella spp. and $H$. akashiwo) observed in the inner part of the Ariake Sea from 29 June to 3 September of 2007 in detail, from the viewpoint of growth competition among these algae. Through laboratory experiments, we investigated the allelopathy of Skeletonema sp. on growth and interspecific interactions of co-occurring harmful flagellates to confirm how the allelopathic effects of this diatom influence interspecific competition and bloom formation among the flagellates.

\section{MATERIALS AND METHODS}

\section{Field surveys}

We reviewed the phytoplankton fluctuation data at 4 stations (Fig. 1) in the inner part of the Ariake Sea during the summer (29 June to 3 September) of 2007, surveyed by Saga Prefectural Ariake Fisheries Research and Development Center. This field survey was conducted once a week in principle, but, where necessary, additional

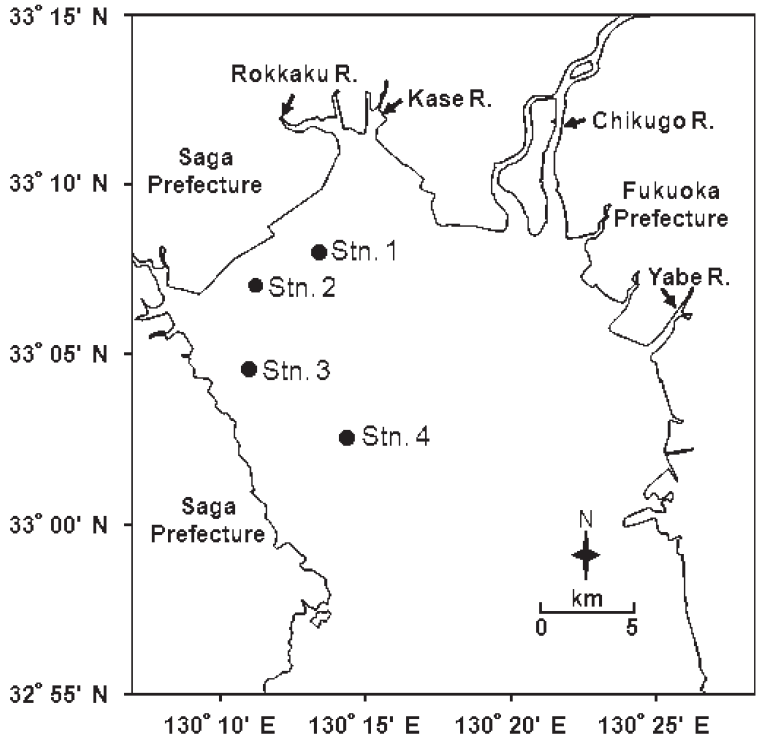

Fig. 1. Location of sampling stations in the inner part of the Ariake Sea, Japan. Arrows indicate main rivers (R.) around this sea area. The filled circles indicate the 4

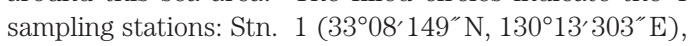
Stn. $2\left(33^{\circ} 07^{\prime} 184^{\prime \prime} \mathrm{N}, 130^{\circ} 11^{\prime} 121^{\prime \prime} \mathrm{E}\right)$, Stn. $3\left(33^{\circ} 04^{\prime} 715^{\prime \prime}\right.$

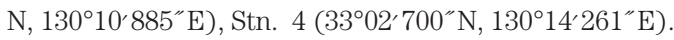

sampling was carried out to follow the development of Chattonella spp. blooms (1 to 28 August, 2007). Seawater was sampled from the surface using plastic bottles, and samples were returned to the laboratory within $4 \mathrm{~h}$ and treated. Surface water temperatures were measured by a thermometer in situ, and water salinity were measured by a digital salinometer (E-202, Tsurumi Seiki, Yokohama, Japan). Dissolved inorganic nitrogen (DIN: $\mathrm{NO}_{2}^{-}, \mathrm{NO}_{3}^{-}$and $\mathrm{NH}_{4}^{+}$) and dissolved inorganic phosphorus (DIP: $\mathrm{PO}_{4}^{3-}$ ) were measured by an auto analyzer (TRACCS 2000, Bran Luebbe, Hamburg, Germany). The water samples in bottles for counting phytoplankton were gently turned upside down 5 times before removing a subsample for counting. Cells of phytoplankton were counted microscopically in $0.5 \mathrm{ml}$ subsamples, and therefore the detection limit was 2.0 cells $\mathrm{ml}^{-1}$. Thus, our estimates were not suitable for analyzing the diversity of the phytoplankton community, but could be used to analyze the succession of predominant species.

\section{Algal species and culture conditions}

Axenic strains of $C$. antiqua (NIES-1), H. akashiwo (NIES-10), and Skeletonema sp. (NIES-324) were obtained from the National Institute of Environmental Studies (NIES, Japan). A. sanguinea was isolated in November 2002 from Hakozaki Harbor in Hakata Bay, Japan, and a demonstrably axenic strain was obtained through repeated washing using capillary pipettes (Matsubara et al., 2007). The above strains were verified as axenic using the 4,6-diamidino-2-phenylindole (DAPI) staining method developed for testing for bacterial contamination (Porter and Feig, 1980). Algal cultures were maintained in $70 \mathrm{ml}$ sterile flasks (Nunc, Thermo Fisher Scientific Inc., Suwanee, GA, USA) containing $20 \mathrm{ml}$ of modified SWM-3 medium (Yamasaki et al. 2007) 
at a salinity of 30. The modified SWM-3 medium contained $0.04 \%$ (w/v) of tris(hydroxymethyl)-aminomethane (Wako Pure Chemical Industries, Ltd., Osaka, Japan) to buffer $\mathrm{pH}$ during the experiments, and the medium was autoclaved before use $\left(121^{\circ} \mathrm{C}, 15 \mathrm{~min}\right)$. Stock cultures were conducted in an incubator (FLI-160, Tokyo Rikakikai Co., Ltd., Tokyo, Japan) at $25^{\circ} \mathrm{C}$ under $250 \pm 8$ umol photons $\mathrm{m}^{-2} \mathrm{~s}^{-1}$ of cool-white fluorescent illumination at a 12:12 h light:dark cycle. Irradiance in the incubator was measured using a Quantum Scalar Laboratory Irradiance Sensor (QSL-2101, Biospherical Instruments, San Diego, CA, USA).

\section{Effects of re-enriched filtrates from Skeletonema sp. cultures on each flagellate}

The diatom Skeletonema sp. was inoculated at a cell density of $1 \times 10^{3}$ cells $\mathrm{ml}^{-1}$ into a $650 \mathrm{ml}$ sterile flask (Nunc) containing $350 \mathrm{ml}$ of modified SWM-3 medium. Culture filtrates were prepared on day 8 once the cell density of Skeletonema sp. reached $1 \times 10^{6}$ cells $\mathrm{ml}^{-1}$ ( $100 \mathrm{ml}$; as a sample of the early stationary phase), on day 20 when cell density reached $6.7 \times 10^{5}$ cells $\mathrm{ml}^{-1}$ ( $100 \mathrm{ml}$; as a sample of the late stationary phase), and on day 26 when cell density reached $5.2 \times 10^{2}$ cells $\mathrm{ml}^{-1}$ ( $100 \mathrm{ml}$; as a sample of the death phase), by passing the cultures through a GF/C membrane filter (Whatman International Ltd., Maidstone, UK) on a $47 \mathrm{~mm}$ polysulfone holder under gravity filtration. Each filtrate (100\% filtrate) was diluted to $50 \%(\mathrm{v} / \mathrm{v})$ with fresh modified SWM-3 medium. To compensate for nutrients consumed by algal growth, the same quantities of nutrients as in the original modified SWM-3 medium were added (reenriched) so that the final nutrient concentration of either filtrate (100\% or $50 \%$ filtrate) was expected to be between 100 and $200 \%$ of the original modified SWM-3 medium. The $\mathrm{pH}$ of each filtrate was adjusted to 7.8-8.0 using $2 \mathrm{~N} \mathrm{HCl}$, and all the media were subsequently passed through $0.22 \mu \mathrm{m}$ syringe filters (Millipore, Billerica, MA, USA).

For the growth experiment in culture filtrates, $A$. sanguinea, $H$. akashiwo, and $C$. antiqua were cultured separately in $8 \mathrm{ml}$ sterile culture tubes (Evergreen Scientific, Los Angeles, CA, USA) containing $5 \mathrm{ml}$ of a prepared test medium. Each flagellate was cultured alone in modified SWM-3 medium (original medium) as a control, and was also cultured alone in modified SWM-3 medium with the nutrient concentration elevated to $200 \%$ of the original medium concentration (re-enriched medium), to evaluate any nutrient inhibitory effect in re-enriched filtrates. The initial cell density of each flagellate was $1 \times 10^{2}$ cells $\mathrm{ml}^{-1}$, with 4 replicate tubes for each treatment. Culture conditions were the same as described in Section 2.2. Relative cell abundances were measured daily using in vivo fluorescence (model 10-AU-005-CE fluorometer; Turner Designs, Sunnyvale, CA, USA). The growth rate $\left(\mathrm{d}^{-1}\right)$ was calculated for each tube from 3 consecutive data points, using the method of Brand et al. (1981), and maximum growth rates during the entire incubation period were determined.
Effects of live Skeletonema sp. cells on each flagellate under non-contact conditions

For this experiment, the diatom and each flagellate were cultured separately in inner and outer wells separated by a membrane with a pore size of $3.0 \mu \mathrm{m}$ in 6 -well plates (BD35-3091; Becton-Dickinson, Franklin Lakes, NJ, USA), as shown in Fig. 2 (modified from Yamasaki et al. 2007). Cells of $A$. sanguinea, H. akashiwo, and $C$. antiqua in early stationary phase were diluted with modified SWM-3 medium, and $5 \mathrm{ml}$ of the resulting cell suspension for each flagellate was inoculated into the outer chambers of the well plates (final cell density: $1 \times 10^{2}$ cells $\mathrm{ml}^{-1}$ ). Subsequently, cells of Skeletonema sp. at early stationary phase were diluted with modified SWM-3 medium, and $3 \mathrm{ml}$ of this cell suspension was inoculated into each inner chamber of the well plates (final cell density: $1 \times 10^{3}$ cells $\mathrm{ml}^{-1}$ ). As controls, $5 \mathrm{ml}$ mono-algal cell suspensions for each flagellate were individually cultured in fresh modified SWM-3 medium (final cell densities: $1 \times 10^{2}$ cells $\mathrm{ml}^{-1}$ ). Three replicate wells were used for each treatment and culture conditions were the same as described in Section 2.2. At 2 d intervals, $100 \mu$ cultures in the outer chambers (flagellates) and $20 \mu \mathrm{l}$ cultures in the inner chambers (Skeletonema sp.) were taken by a 20-200 $\mu$ l Pipette (Nichipet EX, Nichiryo CO., Ltd., Koshigaya, Japan), and cell numbers in those subsamples were counted under a light microscope. When cell densities exceeded $2 \times 10^{4}$ cells $\mathrm{ml}^{-1}$, subsamples were diluted 10 to 50 times with fresh modified SWM-3 medium before counting.

\section{Effect of live Skeletonema sp. cells on growth competitions among flagellates}

This experiment was also conducted using 6-well plates with cell-culture insert plates (Fig. 2). Firstly, cells of A. sanguinea, $H$. akashiwo, and C. antiqua during the exponential growth phase were individually diluted with modified SWM-3 medium, and then mixed

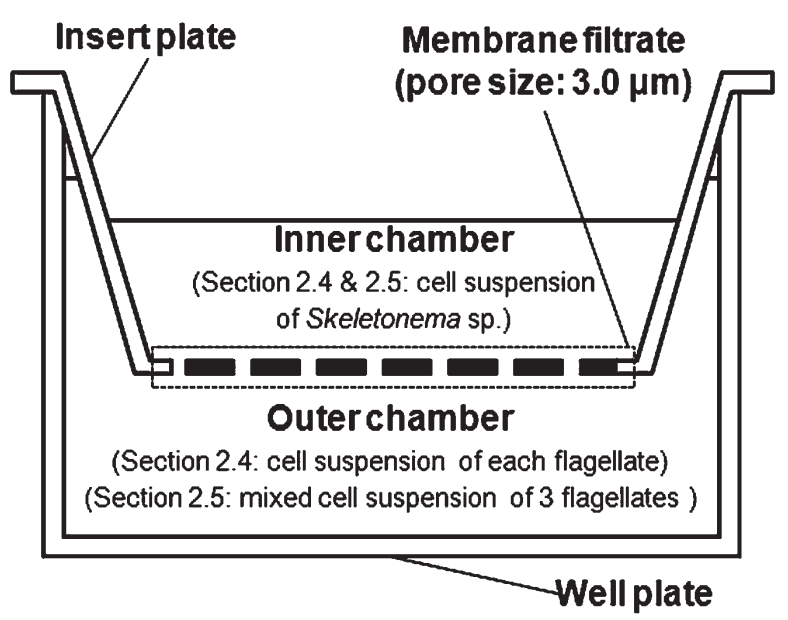

Fig. 2. Cross section of well plate with a BD Falcon cell culture insert used to investigate effects of allelopathic influence of live Skeletonema sp. cells on growth of each flagellates (Section 2.4) and on growth competition among flagellates (Section 2.5). 
together to make mixed cell suspension of flagellates (final cell density for each flagellate: $1 \times 10^{2}$ cells $\mathrm{ml}^{-1}$ ). For tri-algal culture of flagellates under the allelopathic influence of live Skeletonema sp. cells, $5 \mathrm{ml}$ of resulting mixed cell suspension of flagellates was inoculated into the outer chambers of the well plates. Subsequently, cells of Skeletonema sp. at early stationary phase were diluted with modified SWM-3 medium, and $3 \mathrm{ml}$ of this cell suspension was inoculated into the inner chambers of the well plates (final cell density: $1 \times 10^{3}$ cells $\mathrm{ml}^{-1}$ ). For trialgal culture of flagellates without the allelopathic influence of live Skeletonema sp. cells, $5 \mathrm{ml}$ of mixed cell suspension of flagellates was inoculated into each well plate (without the insert plates). Three replicate wells were used for each treatment and culture conditions were the same as described in Section 2.2. At 2 d intervals, $100 \mu \mathrm{l}$ subsamples of cultures in the outer chambers were taken by a 20-200 $\mu$ l Pipette (Nichipet EX, Nichiryo CO., Ltd.), and cell numbers were counted under a light microscope. When cell densities exceeded $2 \times 10^{4}$ cells $\mathrm{ml}^{-1}$, subsamples were diluted 10 to 50 times with fresh modified SWM-3 medium before counting. Growth rates of flagellates during the exponential phase were calculated using the method of Guillard (1973).

\section{Statistical analyses}

The experimental data were checked for assumptions of homogeneity of variance across treatments using Levene's test. If the variances were homogeneous, oneway analysis of variance with Dunnett's test was used to test for differences in the maximum growth rate of each flagellate between the control and different treatments in culture filtrate experiments. An independent sample $\mathrm{T}$ test was employed to test the differences in growth rate of each flagellate at the exponential phase and the proportion of $C$. antiqua cells between the 2 treatments of tri-algal cultures of flagellates. When there was no proof of data homoscedasticity, the Mann-Whitney $U$-test for nonparametric data was used to compare control and treatments. Statistical analyses were conducted using the Statistical Package for the Social Sciences software (SPSS 13.0; SPSS, Inc., Chicago, IL, USA).

\section{RESULTS}

\section{Phytoplankton composition and cell density fluc- tuations}

Fluctuations in cell densities of phytoplankton in the 4 stations are shown in Fig. 3. Cell densities of diatoms Skeletonema spp., flagellates Chattonella spp., $H$. akashiwo, and $A$. sanguinea fluctuated from 0 to $3.1 \times$ $10^{4}$ (on 6 August in Stn. 4, Fig. 3D), $1.3 \times 10^{4}$ (on 24 August in Stn. 2, Fig. 3B), $1.2 \times 10^{4}$ (on 23 July in Stn. 3, Fig. 3C) and $2.4 \times 10^{2}$ (on 31 August in Stn. 3, Fig. 3C) cells $\mathrm{ml}^{-1}$, respectively. Three mono-specific or mixed blooms were observed from 20 to 23 July (in Stn 1-4, Fig. 3), from 6 to 13 August (in Stn 1-4, Fig. 3), and from 20 to 24 August (in Stn. 2 and 3, Fig. 3B and C). During the current field survey, cells of Skeletonema spp. could generally be detected and contributed to the former 2
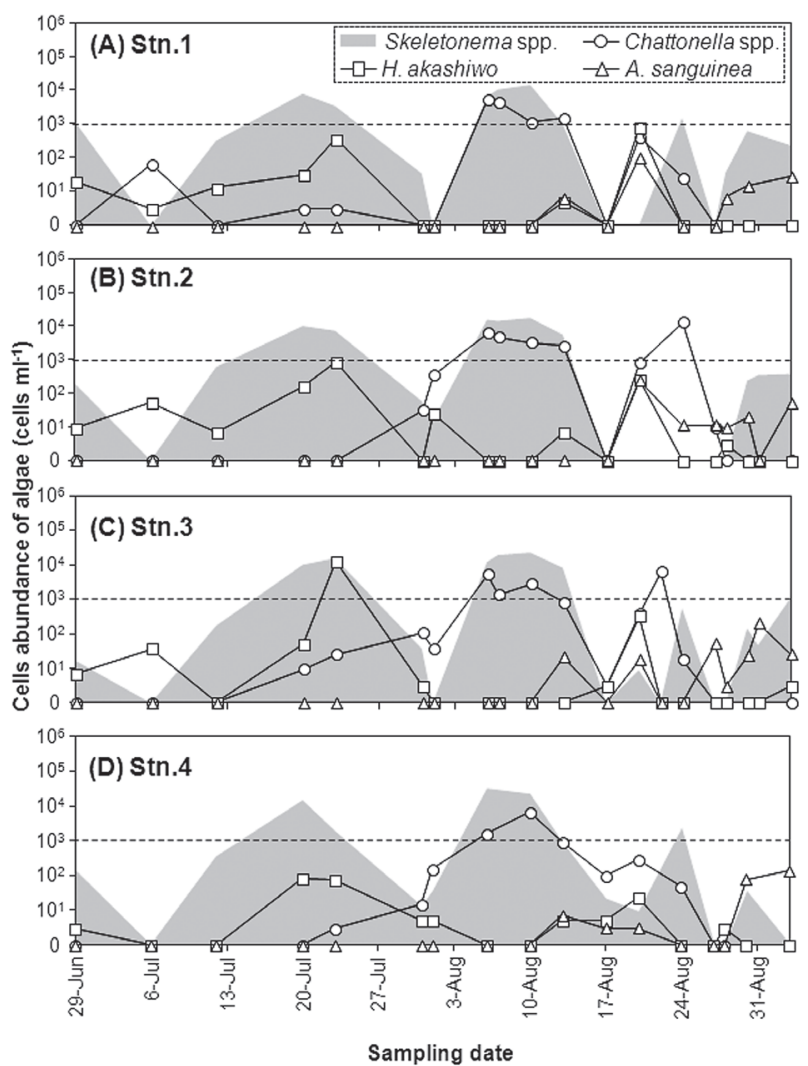

Fig. 3. Fluctuations in cell densities of Skeletonema spp. (gray area), Chattonella spp. (white circle), Heterosigma akashiwo (white box), and Akashiwo sanguinea (white triangle) from 29 June to 3 September 2007, in Stn. 1 (A), Stn. 2 (B), Stn. 3 (C) and Stn. 4 (D).

blooms in all the 4 stations (Fig. 3A-D). From 29 June, cells of $H$. akashiwo could be observed in all the 4 stations and contributed to the first bloom only on 23 July in Stn. 3 (Fig. 3C), but most times its cell densities were lower than $1.0 \times 10^{3}$ cells $\mathrm{ml}^{-1}$. From 6 July, cells of Chattonella spp. were firstly observed in Stn. 1 and were detected in all the 4 stations after 23 July. On 31 July or 1 August, cells of Skeletonema spp., Chattonella spp., and $H$. akashiwo were simultaneously observed at low abundance $\left(<3.4 \times 10^{2}\right.$ cells $\left.\mathrm{ml}^{-1}\right)$. Subsequently, Chattonella spp. and Skeletonema spp. grew rapidly and formed a co-occurring bloom in all the 4 stations from 6 to 13 August (the second bloom, Fig. 3), during when $H$. akashiwo and $A$. sanguinea maintained low cell densities. After the end of the second bloom, Skeletonema spp. maintained low abundance $\left(<2 \times 10\right.$ cells $\left.\mathrm{ml}^{-1}\right)$ and all these flagellates were simultaneously detected to grow from 17 to 20 August, and then only Chattonella spp. formed a dense bloom again from 22 to 24 August in Stn. 2 and 3 (the third bloom, Fig. 3). From 13 August, cells of $A$. sanguinea were firstly observed in Stn. 4 (Fig. 3D), and this flagellate could reach a relatively high cell density (about $2 \times 10^{2}$ cells $\mathrm{ml}^{-1}$ ) only when cells of other algae maintained low densities (Fig. 3).

During the present field survey, surface water temperature increased from 24.5 to $32.7^{\circ} \mathrm{C}$, while the salinity 
showed some relatively acute variations after strong precipitations (from 2 to 6 July and from 2 to 4 August) and varied from 6.4 to 29.4. The nutrients concentrations generally decreased after dense blooms of phytoplankton and increased after strong precipitations: the DIN concentrations varied from 0.26 to $77.43 \mu \mathrm{g}$ at $\mathrm{l}^{-1}$, and the DIP concentration varied from 0.05 to $4.07 \mu \mathrm{g}$ at $\mathrm{l}^{-1}$ (data not shown).

\section{Effects of re-enriched filtrates from Skeletonema sp. cultures on each flagellate}

Growth inhibitory effects of filtrates prepared from the early stationary phase Skeletonema sp. culture (collected on day 8, Fig. 4A) were shown in Fig. 4B. The $100 \%$ filtrate significantly reduced the maximum growth rates of $A$. sanguinea (to $84 \%$ of that of control, $P<0.05$ )
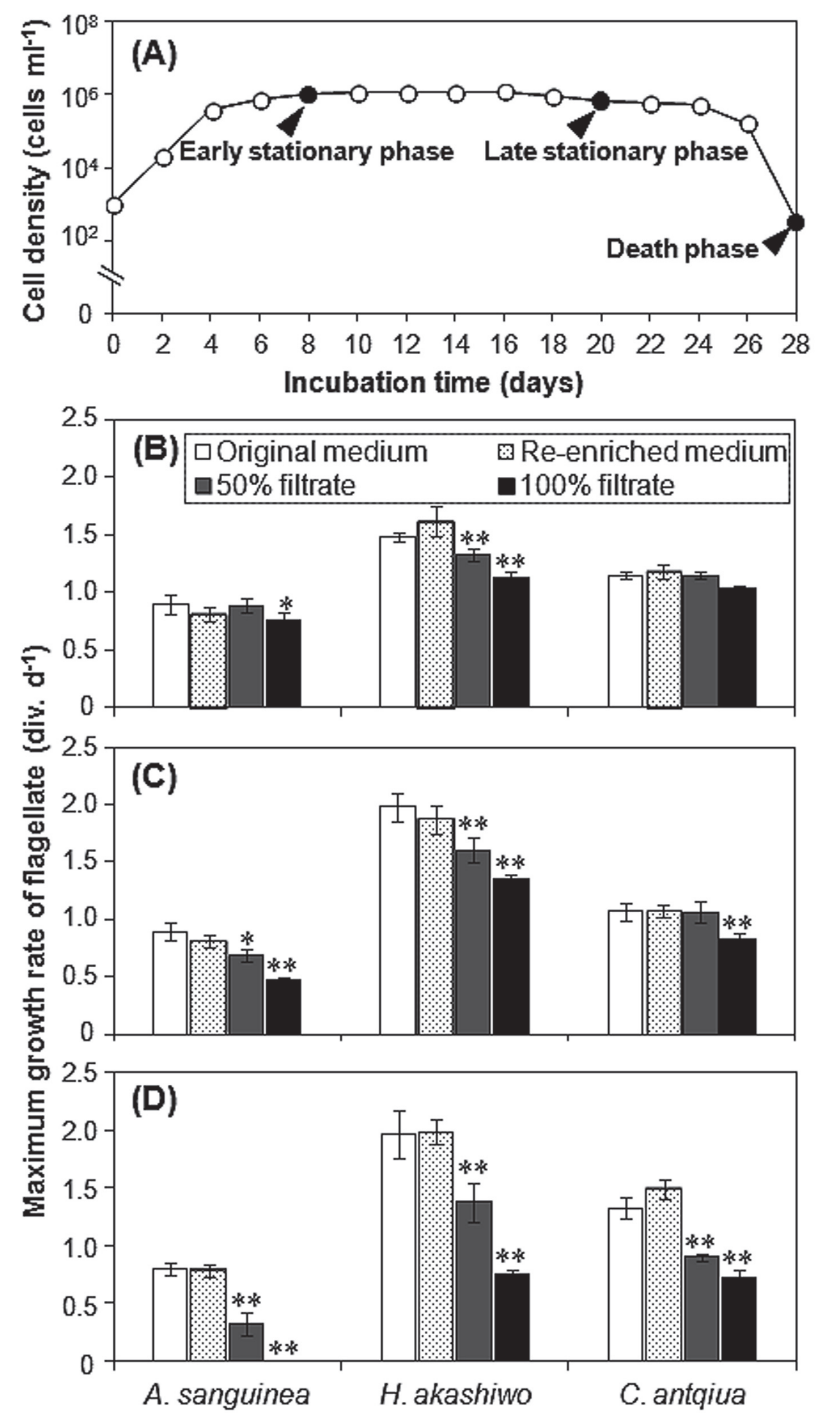

Fig. 4. Effects of filtrates prepared from cultures of Skeletonema sp. on the maximum growth rate of flagellates. (A) Growth curve of Skeletonema sp. showing collection times of filtrates. (B-D) Inhibitory effects of filtrates prepared from cultures of S. Skeletonema sp. at the early stationary phase (B), the late stationary phase (C), and the death phase (D) on the growth of Akashiwo sanguinea, Heterosigma akashiwo, and Chattonella antiqua. Values are means $\pm \operatorname{SD}(n=4)$ and asterisks indicate values that are significantly different $(*: P<0.05 ; * *: P<0.01)$ from controls (cultured in fresh modified SWM-3 medium). and $H$. akashiwo (to $77 \%$ of that of control, $P<0.01$ ); the $50 \%$ filtrates significantly decreased the maximum growth rate of $H$. akashiwo (to $90 \%$ of that of control, $P<0.01$ ), while these filtrates of Skeletonema sp. had little effect on growth of $C$. antiqua.

Growth inhibitory effects of filtrates prepared from the late stationary phase Skeletonema sp. culture (collected on day 20, Fig. 4A) were shown in Fig. 4C. The $100 \%$ filtrates significantly reduced the maximum growth rates of $A$. sanguinea (to $53 \%$ of that of control, $P<0.01$ ), $H$. akashiwo (to $68 \%$ of that of control, $P<0.01$ ), and $C$. antiqua (to $78 \%$ of that of control, $P<0.01$ ); the $50 \%$ filtrates significantly reduced the maximum growth rates of $A$. sanguinea (to $76 \%$ of that of control, $P<0.05$ ) and H. akashiwo (to $81 \%$ of that of control, $P<0.01$ ), but exhibited little inhibitory effect on $C$. antiqua growth (Fig. 4C).

Growth inhibitory effects of filtrates prepared from the death phase Skeletonema sp. culture (collected on day 24, Fig. 4A) were shown in Fig. 4D. The 100\% filtrates exhibited a lethal effect on the growth of $A$. sanguinea, and significantly reduced the maximum growth rates of $H$. akashiwo (to 38\% of that of control, $P<0.01$ ) and $C$. antiqua (to $54 \%$ of that of control, $P<0.01$ ); the $50 \%$ filtrates significantly reduced the maximum growth rates of $A$. sanguinea (to $63 \%$ of that of control, $P<0.01$ ), H. akashiwo (to 70\% of that of control, $P<0.01$ ), and $C$. antiqua (to $68 \%$ of that of control, $P<0.01$ )

The maximum growth rates of the 3 flagellates cultured in re-enriched media were similar to that of cells cultured in the original modified SWM-3 medium (Fig. $4 \mathrm{~B}-\mathrm{D})$, demonstrating that nutrient concentrations in re-enriched filtrates were not responsible for the observed inhibitory effects. Overall, A. sanguinea was the most sensitive species and suffered the highest growth inhibition level, followed by $H$. akashiwo, and C. antiqua was the most resistant species.

\section{Effects of live Skeletonema sp. cells on each flag- ellate under non-contact conditions}

When cultured with each flagellate under non-contact conditions, the growth of Skeletonema sp. was similar to that observed in mono-algal culture (Fig. 5A). In bi-algal culture of $A$. sanguinea and Skeletonema sp. under non-contact conditions, the growth of $A$. sanguinea was strongly inhibited soon after the start of the experiment, with the average maximum cell density of A. sanguinea (on day 6 ) reaching about $6 \%$ of that in

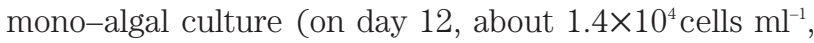
Fig. 5B). In addition, many morphologically abnormal as well as disrupted cells appeared beginning on day 4 when the cell density of the diatom reached $3.4 \times 10^{5}$ cells $\mathrm{ml}^{-1}$. In bi-algal culture of $H$. akashiwo and Skeletonema sp. under non-contact conditions, the growth of $H$. akashiwo was strongly inhibited after day 4 when the cell density of the diatom reached $3.3 \times 10^{5}$ cells $\mathrm{ml}^{-1}$, with the average maximum cell density of $H$. akashiwo (on day 6 ) reaching about $17 \%$ of that in mono-algal culture (on day 12 , about $7.0 \times 10^{5}$ cells $\mathrm{ml}^{-1}$, Fig. 5C). In bi-algal culture of $C$. antiqua and Skeletonema sp. under non-con- 


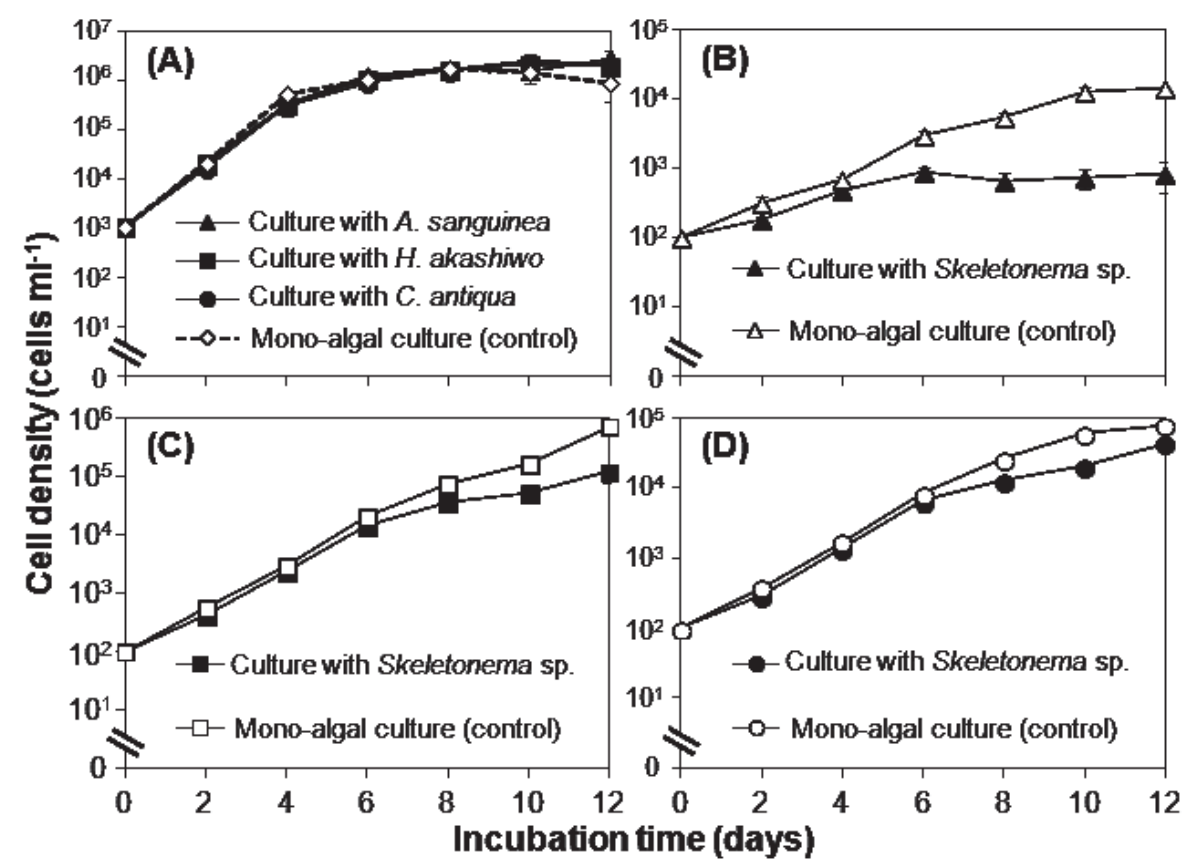

Fig. 5. Growth curves of phytoplankton in mono-algal cultures or bi-algal cultures under noncontact conditions. (A) Growth of Skeletonema sp. (initial cell density: $1 \times 10^{3}$ cells $\mathrm{ml}^{-1}$ ) in mono-algal culture or in bi-algal culture with each flagellate under non-contact conditions. (B-D) Growth of each flagellate (initial cell density: $1 \times 10^{2}$ cells $\mathrm{ml}^{-1}$ ) in mono-algal culture or in bi-algal culture with Skeletonema sp. (initial cell density: $1 \times 10^{3} \mathrm{cells}^{-1} \mathrm{~m}^{-1}$ ) under non-contact conditions: (B) Akashiwo sanguinea, (C) Heterosigma akashiwo, (D) Chattonella antiqua. Values are means $\pm \mathrm{SD}(n=3)$.
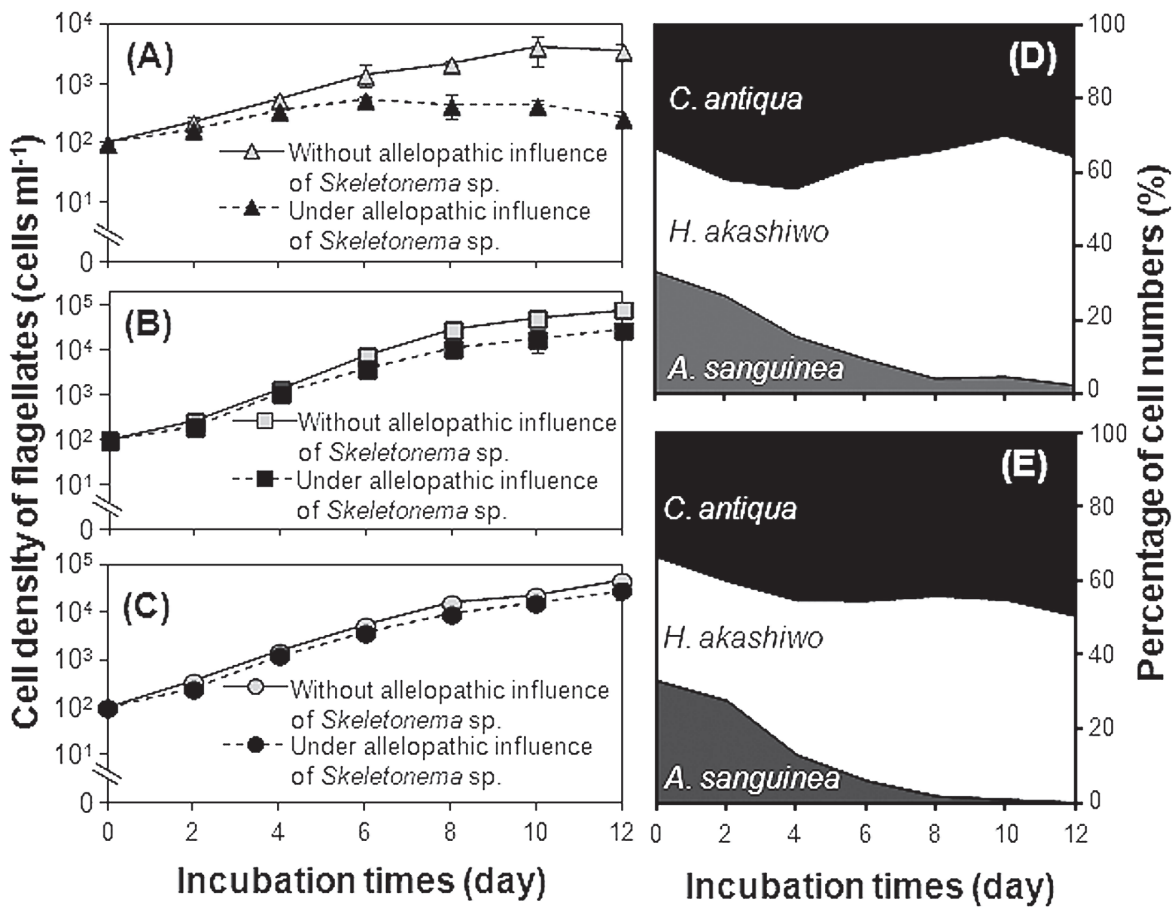

Fig. 6. Effects of allelopathic influence of live Skeletonema sp. cells on interspecific interactions among the 3 flagellates. (A-C) Growth of each flagellate (initial cell density: $1 \times 10^{2}$ cells $\mathrm{ml}^{-1}$ ) in tri-algal cultures without the allelopathic influence of live Skeletonema sp. cells (gray symbols) or under the allelopathic influence of live Skeletonema sp. cells (black symbols): (A) Akashiwo sanguinea, (B) Heterosigma akashiwo, (C) Chattonella antiqua. Values are means $\pm \mathrm{SD}(n=3)$. (D-E) Changes in the proportions of cell numbers of A. sanguinea (gray areas), $H$. akashiwo (white areas), and C. antiqua (black areas) during tri-algal cultures of these flagellates without the allelopathic influence of live Skeletonema sp. cells (D), or under the allelopathic influence of live Skeletonema sp. cells (E). 
tact conditions, the growth of $C$. antiqua was strongly inhibited after day 6 when cell density of the diatom reached $9.4 \times 10^{5}$ cells $\mathrm{ml}^{-1}$ (Fig. 5A), with the average maximum cell density of reaching about $55 \%$ of that in mono-algal culture (on day 12 , about $7.8 \times 10^{4}$ cells $\mathrm{ml}^{-1}$, Fig. 5D). Thus, when cultured together with live Skeletonema sp. cells under non-contact conditions, $A$. sanguinea also exhibited the highest sensitivity and suffered the highest growth inhibition level, followed by $H$. akashiwo, while $C$. antiqua was the most resistant species and experienced the lowest level of growth inhibition.

\section{Effect of live Skeletonema sp. cells on growth competition among flagellates}

In tri-algal culture of flagellates under the allelopathic influence of live Skeletonema sp. cells, the allelopathic influence exhibited higher inhibitory effects on the growth of $A$. sanguinea and $H$. akashiwo than on that of $C$. antiqua, compared with tri-algal culture of flagellates without the allelopathic influence (Fig. 6A-C). The growth rates (from day 2 to day 6 ) of $A$. sanguinea, $H$. akashiwo, and $C$. antiqua were $0.83 \pm 0.10,1.64 \pm 0.21$, and $1.79 \pm 0.10$ div. $\mathrm{d}^{-1}$ in tri-algal culture of flagellates under the allelopathic influence of live Skeletonema sp. cells,, which were reduced to $62 \%(P<0.01), 71 \%(P<$ $0.05)$ and $91 \%(P=0.08)$ of those in tri-algal culture of flagellates without the allelopathic influence, respectively. The allelopathic influence of live Skeletonema sp. cells thus changed the composition of the tri-algal culture of flagellates by increasing the proportion of $C$. antiqua and decreasing that of $A$. sanguinea and $H$. akashiwo (Fig. 6D and E). Changes were particularly marked from day 8 onward $(P<.05)$, and on day 12 the proportion of $C$. antiqua in the tri-algal culture of flagellates without the allelopathic influence of live Skeletonema sp. cells was $35.6 \%$ (total cell density: $1.3 \times 10^{5}$ cells $\mathrm{ml}^{-1}$; Fig. $6 \mathrm{D})$ while that in the tri-algal culture with the allelopathic influence of live Skeletonema sp. cells was 49.3\% (total cell density: $5.6 \times 10^{4}$ cells $\mathrm{ml}^{-1}$; Fig. $6 \mathrm{E}$ ).

\section{DISCUSSION}

Skeletonema spp. are strong competitor of harmful flagellates in nutrient-limited water (Lomas and Glibert, 2000) and in allelopathic interactions (e.g. Matsubara et al., 2008; Yamasaki et al., 2011). When grown in reenriched culture filtrates of Skeletonema sp. (Fig. 4) and cultured with Skeletonema sp. under non-contact conditions (Fig. 5), growth of the 3 flagellates tested was inhibited at different intensities. Since the $\mathrm{pH}$ values in each re-enriched filtrate of Skeletonema sp. was adjusted to the level of that in control before testing (see section 2.3), and none of the $\mathrm{pH}$ values in bi-algal cultures (see section 2.4) exceeded 8.5 at the end of cultivation (data not shown), these inhibitory effects were not caused by nutrient limitation, elevated $\mathrm{pH}$ values (e.g. Lundholm et al., 2005), or direct cell contact (Uchida, 2001). Therefore, all these flagellates experienced allelopathic inhibitory effects from the diatom. Although the substances inducing allelopathic effects of Skeletonema sp. were not clear, Yamasaki et al. (2011) reported that the allelochemicals are likely to be chemically stable, low molecular weight substances. Furthermore, our results also suggested that $A$. sanguinea suffered the highest growth inhibition level from Skeletonema sp., followed by $H$. akashiwo, while $C$. antiqua was the most resistant. These results are in good agreement with previous field observations (Honjo et al., 1978; Matsubara et al., 2008; Yamasaki et al., 2010) and strongly support the conclusion that the allelochemicals produced by Skeletonema sp. have species-specific effects on phytoplankton (Imada et al., 1991; Yamasaki et al., 2011).

Allelochemicals can not only benefit the releaser species by decreasing the number of competitors, but also benefit any species that is not so sensitive to the compounds (Fistarol et al., 2004). Since C. antiqua is more resistant to allelopathic effects of Skeletonema sp. than $H$. akashiwo and $A$. sanguinea, the former flagellate may obtain some benefit to from bloom when those algae co-existed. This assumption was confirmed by tri-algal culture of flagellates under the allelopathic influence of live Skeletonema sp. cells (Section 2.5): the results showed that allelopathic effects of Skeletonema sp. increased the proportion of $C$. antiqua and reduced those of $H$. akashiwo and $A$. sanguinea, compared with that

Table 1. Summary of some physical and chemical conditions affecting the growth of Akashiwo sanguinea, Heterosigma akashiwo, and Chattonella antiqua.

\begin{tabular}{|c|c|c|c|c|c|c|}
\hline \multirow{2}{*}{ Flagellates } & \multicolumn{3}{|c|}{ Physical conditions ${ }^{\text {a }}$} & \multicolumn{3}{|c|}{ Chemical conditions $\left(K s, \mu \mathrm{g} \text { at } \mathrm{l}^{-1}\right)^{\mathrm{b}}$} \\
\hline & Temp. $\left({ }^{\circ} \mathrm{C}\right)$ & Salinity & References & Nitrogen & Phosphorus & References \\
\hline A. sanguinea & $\begin{array}{l}10.0-30.0 \\
(25.0)\end{array}$ & $\begin{array}{l}10.0-40.0 \\
(20.0)\end{array}$ & $\begin{array}{l}\text { Matsubara } \\
\text { et al., } 2007\end{array}$ & $0.78-1.22$ & No data & $\begin{array}{l}\text { Kudela et } a l . \text {, } \\
2008\end{array}$ \\
\hline C. antiqua & $\begin{array}{l}15.0-32.5 \\
(30.0)\end{array}$ & $\begin{array}{l}16.0-36.0 \\
(28.0)\end{array}$ & $\begin{array}{l}\text { Yamatogi } \\
\text { et al., } 2006\end{array}$ & $1.99-2.45$ & 1.9 & $\begin{array}{l}\text { Nakamura, } \\
1985\end{array}$ \\
\hline H. akashiwo & $\begin{array}{l}10.0-32.5 \\
(25.0)\end{array}$ & $\begin{array}{l}16.0-36.0 \\
(24.0)\end{array}$ & $\begin{array}{l}\text { Yamatogi } \\
\text { et al., } 2006\end{array}$ & $1.99-2.45$ & $1.0-1.98$ & Tomas, 1979 \\
\hline
\end{tabular}

\footnotetext{
${ }^{a}$ The temperature (Temp.) and salinity values are reported as the ranges for reproduction, and suitable conditions for

Values are the half saturation constant $\left(K s, \mu \mathrm{g}\right.$ at $\left.\mathrm{l}^{-1}\right)$ of the incorporation for nitrogen and phosphorus, respectively.
} 
in tri-algal culture of flagellates without the allelopathic influence of live Skeletonema sp. cells (Fig. 6D, E). Our previous studies indicated that the combination of initial cell densities are critical in determining the successful species in growth competition between $C$. antiqua and $H$. akashiwo / A. sanguinea: the species that first reached the early stationary phase tended to strongly inhibit growth of the other alga in bi-algal cultures (Qiu et al., 2011a, 2011b). Therefore, allelopathy of Skeletonema spp. has potential to influence interspecific competition of these flagellates owing to species-specific growth inhibitory effects, and sometimes give C. antiqua a competitive advantage against the others.

In the Ariake Sea, Japan, physicochemical factors certainly play large roles in bloom formations of phytoplankton (e.g. Nakamura and Hirata, 2006; Tsutsumi, 2006). A summary of some physical and chemical factors affecting the growth of these 3 flagellates is shown in Table 1. The fluctuations in physicochemical factors during the current field survey have been described in detail by Matsubara et al., 2009. The average surface water temperature ranged from 24.8 to $29.8^{\circ} \mathrm{C}$, and most times the average salinity ranged from 15 to 30 . Under these conditions, the growth rate of $C$. antiqua and $H$. akashiwo isolated from the Ariake Sea was reported at 1.0-1.43 and 1.2-1.64 div. day ${ }^{-1}$, respectively (Yamatogi et al., 2006), the growth rate of $A$. sanguinea isolated from Hakata Bay (near the Ariake Sea) ranged from 0.4 to 1.13 div. day ${ }^{-1}$ but drastically decreased if the salinity was $<20$ (Matsubara et al., 2007). Therefore, most times the water temperature and salinity were suitable for the growth of these flagellates except the periods of relatively low salinity (from 6 to 12 July and around 6 August) after strong precipitations. The concentrations of dissolved inorganic nitrogen (DIN) and dissolved inorganic phosphorous (DIP) in the surface water, which were more than $50 \mu \mathrm{g}$ at $\mathrm{l}^{-1}$ and $2.5 \mu \mathrm{g}$ at $\mathrm{l}^{-1}$ just before the first blooms (12 July), decreased to less than $10 \mu \mathrm{g}$ at $\mathrm{l}^{-1}$ and $1 \mu \mathrm{g}$ at $\mathrm{l}^{-1}$, respectively, during these blooms (from 23 July to 20 August, Matsubara et al., 2009). However, when the cell density of Skeletonema spp. was $\geq 1.0 \times 10^{3}$ cells $\mathrm{ml}^{-1}$, that of $H$. akashiwo was usually $<1.0 \times 10^{3}$ cells $\mathrm{ml}^{-1}$ (except in Stn. 3, Fig. 3C) and that of $A$. sanguinea was generally below detection level, while Chattonella spp. could reach high density and form mixed blooms with the diatoms (Fig. 3). Therefore, Blooms of Skeletonema spp. may also have a role in regulating algal succession and bloom formation of co-occurring flagellates in the Ariake Sea, associated with changes in physicochemical factors such as relatively low salinity or nutrient concentrations.

The present laboratory experiments have suggested that Skeletonema spp. may influence bloom formation of co-occurring flagellates in 2 ways by its species-specific allelopathic effects: (1) directly suppress their growth at different levels; (2) influence interspecific interactions among flagellates and give $C$. antiqua a competitive advantage over $H$. akashiwo and $A$. sanguinea. These results are in accordance with fluctuations in cell densities of these flagellates observed during the field surveys. From 12 June to 23 July, 2007, the allelopathic effects of bloomed Skeletonema spp. may play a role in inhibiting the growth of $H$. akashiwo and $A$. sanguinea and keeping their cell densities at low levels or below detection level (Fig. 3). After appearance (germination) of Chattonella spp., the allelopathic effects of Skeletonema spp. may give Chattonella spp. an advantage and enable them to form dense blooms, while growth of other 2 flagellates was strongly suppressed by the inhibitory effects from mixed blooms of Chattonella spp. and Skeletonema spp. (from 6 to 13 August, Fig. 3).

In this field survey, the maximum density of Skeletonema spp. was $<5 \times 10^{4}$ cells $\mathrm{ml}^{-1}$ (Fig. 3); much lower than the 'threshold value' for strong inhibition of flagellate growth observed in the laboratory experiments $\left(>10^{5}\right.$ cells $\mathrm{ml}^{-1}$, Fig. 5). Mikhail (2007) reported that a bloom of $C$. antiqua was preceded by increased numbers of Skeletonema, and that during the bloom of $C$. antiqua in combination with Skeletonema (about $10^{3}$ cells $\mathrm{ml}^{-1}$ ) the cell density of $H$. akashiwo did not exceed 150 cells $\mathrm{l}^{-1}$ during summer of 2006 in waters of Alexandria, Egypt. Katano et al. (2012) reported that the total abundance of dinoflagellates (including $A$. sanguinea) was always at low level during an alternating bloom of Chattonella and Skeletonema, while cell density of Chattonella also declined when that of Skeletonema reached at $>10^{5}$ cells $\mathrm{ml}^{-1}$ during summer of 2010 in the Ariake Sea. It is likely that only a suitable abundance of Skeletonema spp. $\left(<10^{5}\right.$ cells $\left.\mathrm{ml}^{-1}\right)$ will give Chattonella spp. a competitive advantage to form a bloom against other flagellates, and a higher abundance of the diatoms may also strongly inhibit growth of Chattonella by allelopathic effects and nutrient competition (Lomas and Glibert, 2000). It should be remembered, however, that the laboratory experiments were conducted under axenic conditions in a culture medium with artificially high nutrient levels, and culture conditions such as temperature, light intensity, photoperiod, and salinity were artificially fixed. Further studies of how variations in such environmental factors and direct cell contact between algae (Uchida, 2001) affect allelopathic effects of Skeletonema spp. are necessary.

Overall, our study has demonstrated that the allelopathy of Skeletonema spp. at a suitable abundance has potential to mediate interspecific interactions and change community composition of co-occurring flagellates owing to species-specific growth inhibition levels, which may have a role in regulating bloom formation during summer in the Ariake Sea, Japan. To clarify the proportion of allelopathy of Skeletonema spp. in mediating bloom formations of these co-occurring species, it is necessary to determine the effects of various environmental factors on the production and transmission of allelochemicals, and to verify the role of allelopathy in a further study of a natural phytoplankton population.

\section{ACKNOWLEDGMENTS}

We thank Mie Prefecture Fisheries Research Institute for lending the 10-AU fluorometer (Turner Designs). 
This study was partially supported by FY2012 JSPS Postdoctoral Fellowship for Foreign Researchers (P12405) and the Research Grant for Young Investigators of the Faculty of Agriculture, Kyushu University, Japan.

\section{REFERENCES}

Brand, L. E., R. R. L. Guillard, and L. S. Murphy 1981 A method for the rapid and precise determination of acclimated phytoplankton reproductive rates. J. Plankton Res., 3: 193-201

Fistarol, G. O., C. Legrand, E. Selander, C. Hummert, W. Stolte and E. Granéli 2004 Allelopathy in Alexandrium spp.: effect on a natural plankton community and on algal monocultures. Aquat. Microb. Ecol., 35: 45-56

Flynn, K. J. 2008 Attack is not the best form of defense: lessons from harmful algal bloom dynamics. Harmful Algae, 8: 129139

Granéli, E. and P. J. Hansen 2006 Allelopathy in harmful algae: a mechanism to compete for resources? In "Ecology of Harmful Algae”, ed. by E. Granéli and J. T. Turner, Springer-Verlag, Berlin, pp. 189-201

Granéli, E., M. Weberg and P. S. Salomon 2008 Harmful algal blooms of allelopathic microalgal species: The role of eutrophication. Harmful Algae, 8: 94-102

Guillard, R. R. L. 1973 Division rates. In "Handbook of Phycological Methods: Culture Methods and Growth Measurements", ed. by J. R. Stein, Cambridge University Press, Cambridge, pp. 289-311

Honjo, T. 1993 Overview on bloom dynamics and physiological ecology of Heterosigma akashiwo. In "Toxic Phytoplankton Blooms in the Sea", ed. by T. J. Smayda and Y. Shimizu, Elsevier, New York, pp. 33-41

Honjo, T., T. Shimouse and T. Hanaoka 1978 A red tide occurred at the Hakozaki fishing port, Hakata Bay, in 1973. The growth process and the chlorophyll content. Bull. Plankton Soc. Jpn., 25: $7-12$

Imada, N., K. Kobayashi, K. Takara and Y. Oshima 1991 Production of an autoinhibitor by Skeletonema costatum and its effect on the growth of other phytoplankton. Nippon Suisan Gakk., 57: 2285-2290

Jonsson, P. R., H. Pavia and G. Toth 2009 Formation of harmful algal blooms cannot be explained by allelopathic interactions. P. Natl. Acad. Sci. USA., 106: 11177-11182

Katano, T., K. Yoshino, T. Matsubara and Y. Hayami 2012 Wax and wane of Chattonella (Raphidophyceae) bloom with special reference to competition between Skeletonema (Bacillariophyceae) in the Ariake Sea, Japan. J. Oceanogr., 68: $497-507$.

Kudela, R. M., J. Q. Lane and W. P. Cochlan 2008 The potential role of anthropogenically derived nitrogen in the growth of harmful algae in California, USA. Harmful Algae, 8: 103-110

Legrand, C., K. Rengefors, G. O. Fistarol, and E. Granéli 2003 Allelopathy in phytoplankton-biochemical, ecological and evolutionary aspects. Phycologia, 42: 406-419

Lomas, M. W. and P. M. Glibert 2000 Comparisons of nitrate uptake, storage, and reduction in marine diatoms and flagellates. J. Phycol., 36: 903-913

Lundholm, N., P. J. Hansen and Y. Kotaki 2005 Lack of allelopathic effects of the domoic acid-producing marine diatom Pseudonitzschia multiseries. Mar. Ecol. Prog. Ser., 288: 21-33

Maestrini, S. Y. and D. J. Bonin 1981 Allelopathic relationships between phytoplankton species. Can. Bull. Fish. Aquat. Sci., 210: $323-338$

Matsubara, T., S. Nagasoe, Y. Yamasaki, T. Shikata, Y. Shimasaki, Y., Oshima and T. Honjo 2007 Effects of temperature, salinity, and irradiance on the growth of the dinoflagellate Akashiwo sanguinea. J. Exp. Mar. Biol. Ecol., 342: 226-230

Matsubara, T., S. Nagasoe, Y. Yamasaki, T. Shikata, Y. Shimasaki, Y., Oshima and T. Honjo 2008 Inhibitory effects of centric diatoms on the growth of the dinoflagellate Akashiwo sanguinea. Nippon Suisan Gakk., 74: 598-606
Matsubara, T., Y. Yoshida and K. Kuno 2009 A series of two red tides of Chattonella spp. occurred in Saga Ariake Sea in summer, 2007. Bull. Saga Prefectural Ariake Fisher. Exp. Sta., 24: $39-47$

Mikhail, S. K. 2007 First monospecific bloom of the harmful raphidophyte Chattonella antiqua (Hada) Ono in Alexandria waters related to water quality and copepod grazing. Chem. Ecol., 23: 393-407

Nakamura, Y. 1985 Kinetics of nitrogen- or phosphorus-limited growth and effects of growth conditions on nutrient uptake in Chattonella antiqua. J. Oceanogr. Soc. Jpn., 41: 381-387

Nakamura, Y. and A. Hirata 2006 Plankton community structure and trophic interactions in a shallow and eutrophic estuarine system, Ariake Sound, Japan. Aquat. Microb. Ecol., 44: 45-57

Porter, K. G. and Y. S. Feig 1980 The use of DAPI for identifying and counting aquatic microflora. Limnol. Oceanogr., 25: 943948

Poulson, K. L., R. D. Sieg, E. K. Prince and J. Kubanek 2010 Allelopathic compounds of a red tide dinoflagellate have species-specific and context-dependent impacts on phytoplankton. Mar. Ecol. Prog. Ser., 416: 69-78

Qiu, X., Y. Yamasaki, Y., Shimasaki, H. Gunjikake, T. Matsubara, S. Nagasoe, T. Etoh, S. Matsui, T. Honjo and Y. Oshima 2011a Growth interactions between the raphidophyte Chattonella antiqua and the dinoflagellate Akashiwo sanguinea. Harmful algae, 11: 81-87

Qiu, X., Y. Yamasaki, Y., Shimasaki, H. Gunjikake, T. Shikata, T. Matsubara, S. Nagasoe, T. Etoh, S. Matsui, T. Honjo and Y. Oshima 2011b Growth interactions between raphidophytes Chattonella antiqua and Heterosigma akashiwo. Thalassas, 27: $33-45$

Rice, E. L. 1984 Allelopathy, $2^{\text {nd }}$ ed. Academic Press, London

Smayda, T. J. 1997 Harmful algal blooms: Their ecophysiology and general relevance to phytoplankton blooms in the sea. Limnol. Oceanogr., 42: 1137-1153

Suikkanen, S., G. O. Fistarol and E. Granéli 2005 Effects of cyanobacterial allelochemicals on a natural plankton community. Mar. Ecol. Prog. Ser., 287: 1-9

Tillmann, U., U. John and U. Cembella 2007 On the allelochemical potency of the marine dinoflagellate Alexandrium ostenfeldii against heterotrophic and autotrophic protists. $J$. Plankton Res., 29: 527-543

Tomas, C. R. 1979 Olisthodiscus luteus (Chrysophyceae). III. Uptake and utilization of nitrogen and phosphorus. J. Phycol., 15: $5-12$

Tsutsumi, H. 2006 Critical events in the Ariake Bay ecosystem: Clam population collapse, red tides, and hypoxic bottom water. Plankton Benthos Res., 1: 3-25

Uchida, T. 2001 The role of cell contact in the life cycle of some dinoflagellate species. J. Plankton Res., 23: 889-891

Weissbach, A., M. Rudström, M. Olofsson, C. Béchemin, J. Icely, A. Newton, U. Tillmann and C. Legrand 2011 Phytoplankton allelochemical interactions change microbial food web dynamics. Limnol. Oceanogr., 56: 899-909

Yamasaki, Y., S. Nagasoe, M. Tameishi, T. Shikata, Y. Zou, Z. Jiang, T. Matsubara, Y. Shimasaki, K. Yamaguchi, Y. Oshima, T. Oda and T. Honjo 2010 The role of interactions between Prorocentrum minimum and Heterosigma akashiwo in bloom formation. Hydrobiologia, 641: 33-44

Yamasaki, Y., S. Nagasoe, T. Matsubara, T. Shikata, Y. Shimasaki, Y., Oshima and T. Honjo 2007 Allelopathic interactions between the bacillariophyte Skeletonema costatum and the raphidophyte Heterosigma akashiwo. Mar. Ecol. Prog. Ser., 339: 83-92

Yamasaki, Y., Y. Ohmichi, T. Shikata, M. Hirose, Y. Shimasaki, Y. Oshima and T. Honjo 2011 Species-specific allelopathic effects of the diatom Skeletonema costatum. Thalassas, $\mathbf{2 7}$ : 21-32

Yamatogi, T., M. Sakaguchi, M. Iwataki and K. Matsuoka 2006 Effects of temperature and salinity on the growth of four harmful red tide flagellates occurring in Isahaya Bay in Ariake Sound, Japan. Nippon Suisan Gakk., 72: 160-168 